\title{
Memorial to Prof. Cláudio Melo
}

\author{
Carlos Almir Monteiro de Holanda ${ }^{1}$. Carlos Boabaid Neto ${ }^{2} \cdot$ Cezar Otaviano Ribeiro Negrão ${ }^{3}$. \\ Diogo Lôndero da Silva ${ }^{4}$. . Gustavo Portella Montagner ${ }^{5}$. Jackson Braz Marcinichen ${ }^{6}$. \\ Joaquim Manoel Gonçalves ${ }^{2} \cdot$ Luciana Wasnieveski da Silva de Luca Ramos $^{7}$
}

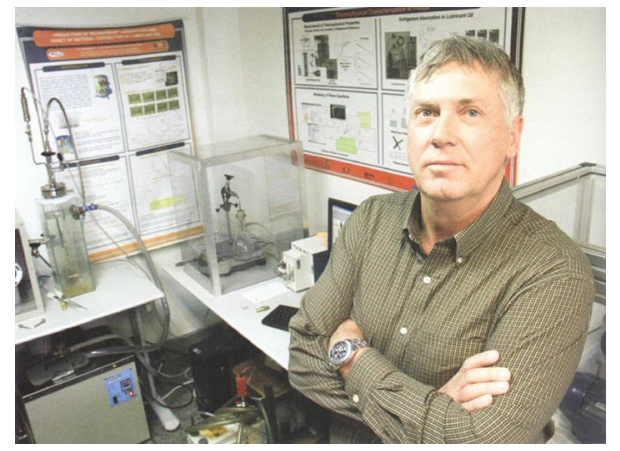

(1955-2019)

Technical Editor: Marcelo Areias Trindade.

Diogo Lôndero da Silva

diogo.londero@ufsc.br

1 Centro de Tecnologia, Universidade Federal do Ceará, Fortaleza, Brazil

2 Instituto Federal de Santa Catarina - Campus São José, Área de Refrigeração e Climatização, São José, SC, Brazil

3 Departamento de Mecânica, Centro de Pesquisa em Reologia e Fluidos Não Newtonianos, Universidade Tecnológica Federal do Paraná, Curitiba, PR, Brazil

4 Laboratório de Refrigeração Veicular, Departamento de Engenharias da Mobilidade, Universidade Federal de Santa Catarina, Joinville, SC, Brazil

5 Departamento de Pesquisa e Desenvolvimento, Embraco, Joinville, SC, Brazil

6 JJ Cooling Innovation Sàrl, EPFL Innovation Park, Lausanne, Switzerland

7 Núcleo de Bionanomanufatura, Instituto de Pesquisas Tecnológicas, São Paulo, Brazil

\section{Memorial}

Cláudio Melo, Professor of the Mechanical Engineering Department of the Federal University of Santa Catarina (UFSC) since 1979, Director of the Research Laboratories for Emerging Technologies in Cooling and Thermophysics (POLO), husband, father and grandfather, passed away on May 28, 2019. Through his teaching and research, he has greatly contributed to advancing the mechanical sciences and engineering in Brazil, in the areas of refrigeration and air-conditioning.

Prof. Melo received a Mechanical Engineering degree from the Federal University of Santa Catarina in 1977, a master degree in Mechanical Engineering from the same university in 1980 and a PhD in Applied Thermal Engineering from Cranfield University in 1985 . He was a co-founder of the POLO Laboratories, which during his professional career was recognized as a National Institute of Science and Technology in Refrigeration and Thermophysics and established as an international reference center for basic and applied research in refrigeration.

In the late 1970s, before joining UFSC, Prof. Melo taught at the Federal Institute of Santa Catarina (IFSC), Campus Florianópolis (then the Federal Technical School of Santa Catarina-ETFSC). Since the 1990s, he maintained a close relationship with the Refrigeration and Air-Conditioning Department at the IFSC Campus São José. This partnership facilitated training opportunities, internships and professional careers to nearly one hundred refrigeration technician students. It is noteworthy that the majority of the teaching staff in that department, which has trained more than 1000 technicians, were students of Prof. Melo at various levels (undergraduate, masters and doctorate).

Prof. Melo gained international recognition from the academic and industrial sectors and will be remembered for his relevant experimental and theoretical contributions to the development of refrigeration cycles, simulation of thermal systems, capillary tubes, expansion valves, heat exchangers, 
thermal insulation, frost formation, defrosting strategies and refrigerant charge minimization. In addition to contributing to the education of several students and professionals, his work had a remarkable impact on the worldwide effort to reduce energy consumption and preserve natural resources. His knowledge and entrepreneurial skills were determinant to establishing solid partnerships between UFSC and companies like Embraco, Whirlpool and Embraer. In recognition to his extensive technical contributions, he received honors from some of those companies and from the Brazilian Society of Mechanical Sciences and Engineering (ABCM).
Prof. Melo's most important achievement, the POLO Laboratories, will stand strong on the shoulders of his colleagues, staff, students and industrial partners. His pragmatism, drive, charisma and energy will be always remembered, motivating the Brazilian HVAC\&R community to carry his legacy on.

Publisher's Note Springer Nature remains neutral with regard to jurisdictional claims in published maps and institutional affiliations. 